\title{
Improved Method for Detection of Cystic Fibrosis Protein in Serum Using the LKB Multiphor Electrofocusing Apparatus
}

\author{
GREGORY B. WIISON “" PHILIPPI: ARNAUI). AND H. HUGH FUDFNBFR( \\ Deparment of Basic and Clinical Immumology and Microbiology, Medical University of South Carolina, \\ (harleston, South Carolima. USA
}

\begin{abstract}
Summary
We have developed an improved method for the detection of cystic fibrosis protein (CFP). The method employs the LKB Multiphor to electrofocus whole serum, instead of the apparatus used in previous studies. Two basic modifications were necessary: ( 1 ) a pH 2.5-10.0 gradient instead of a pH 5-10 gradient, and $(2)$ constant power for focusing the serum proteins instead of constant voltage. The first modification ensured adequate dissolution of the CFP-IgG complexes (or other precursor complexes which may liberate CFP). The second modification ensured a linear gradient (between $\mathrm{pH} 3.8$ and $\mathrm{pH} 9.2$ ), excellent resolution in the pH 8-9 region, and the separation of CFP within $2 \mathrm{hr}$ without overheating of the gel.
\end{abstract}

Electrofocusing with the LKB Multiphor permits the detection of CFP in as many as $\mathbf{2 4}$ serum samples per gel. Results obtained from the analysis of 31 cystic fibrosis, 28 obligate heterozygote carrier, and 28 normal control sera indicate that CFP can be reproducibly and accurately detected in sera using the LKB Multiphor.

\section{Speculation}

Strict adherence to our methods of serum sample collection, processing, storage, and the methods described for the detection of CFP using the LKB Multiphor electrofocusing apparatus may ensure the successful use of our technique to detect CFP and to determine individuals with the $\mathrm{CF}$ gene. 


\section{INIHUOUCTIIUN}

Previous reports trom our laboratory have shown that a cystic tibrosis prote in (CTP) can be detected in sera trom most (F patients (hamozyyutes for Cr) an heterozygotes for CF by analytical isoelectric focusing $(11,12\}$. A standard-

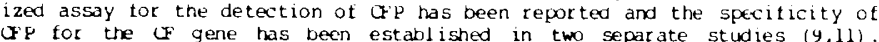
W. for the $\&$ gene has been establ ished in two separate studies $(y, 11)$. Previously we characterized GP as a cationic protein with an isoelectric
point (PI) near pH 8.5 and a molecular weight of $3,506-10.000$ which can be point (pI) near pH 8.5 and a molecular weight of $3,506-10,000$ which can be properties of (r) resemble those established for the "Cr factors" described by rave have restich poposal (14) that (I.P may de similar to a $(F-C D F$ which we have isolated (15).

The standardized assay tor ap detection previously proposed as a use.tul (11), was developed tor use with the electrotœusing equipment describeu by Awdeh et al. (3,7). The electrotocusing apparatus infortunately is no readily available since it is not conmercially produced $(8,13)$. Theretore. indicated previously $(8,16,13)$ that we were exploring the use ot the. LKU Indicated previously $(8,10,13)$ that we were exploring the use of the LK
Multiphor electrotocusing apparatus tor the detection of CfP and compar ing th
results with our results obtained using the apparatus of Awdeh et al. $(3,7)$.

In the present report the complete methodolayy tor the detection of (rP usin the LKH Multiphor is descr ibed. A color photury raph is provided to clar ity the results aotained with our method.

MATERIALS AND ME'THOOS

collection and processing of sumples

venous blood trom normal individuals, patient controls with bronchial asthma, $\mathrm{CF}$ homozyotes, and ool iyate heterozyyotes tor CF were collected and processed as described previously $(8,11,13)$. The patients with brunchial asthma served as controls to recherk the specificity of of tor the (F gene All serum samples were stored trozin at $-7 y$ a until analyzed by electrolocusing.
Informed consent was (x)tained tram all subjects (or in the case ot minors fram the ir parents) frior to obtainion a vluod sample.

Quantitation of IgG

The concentration of IgG in exen serur. sample was determined by single radial imm unodit $t$ usion as descr ided previously (11)

Isoelectric tocusing

Isoelectric toxusing in thin-layer polyacrylamide yele utilizing the appar atu of Awdeh et al. $(3,7)$ was per tomeu in a it 5 -ib gradient exactly as previously described (11). Additional details of the tectnicue and pre-
cautions concerning the method and sample collection and processing have cautions concerning the method
recently been reported $(8,13)$.

isvelectric tocusing in thin-layer polyacrylamide yel using the I.Ke Multiptios (Model 2117-411, LKe fradukter, broma, Sweden) was perturmend uy modilicat lo of the proceduces descrioed previousl $i(8,11)$ tor use of the apparatus of Awdeh et al. $(3,7)$. The electrade solutions and yel composition were
identical to those described $(8)$ except that a yradient ot pit 2.5-1v.v was

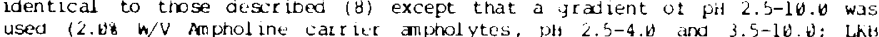

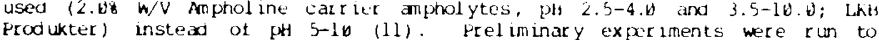
compare the results of tained using the LKB Multiphor with pH $5-10$ and $2.5-14.0$ gradients. IThe use of a more acidic ptl near the anode favored the demonstra-

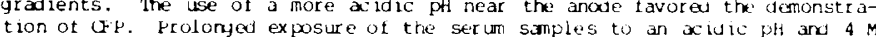
urea is also thought to tavor the demonstration of (ip (8), possibly due to the dissal ution of IgG-cr. complexes or the alteration of some other prexur sor

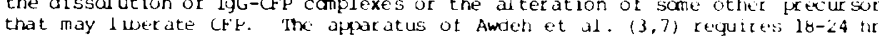
to focus (11,12), whereas the Lk M Multiphor requires only 2 he (see below). Since the samples are exposed to acidic conditions tor onl 2 hr, a more
acidic ph may enhance liberation of (re $(8,13,15$ ).

The gel was petocused at $350 \mathrm{~V}$ (constant vol taje) tor $3 b \mathrm{~min}$. Samples appl ied onto 6X8 mun pads of whatman 3MM chromatuyraphy paper placed with the lower edye of the pad $5 \mathrm{~mm}$ trom the anodal strip. The yel was toc usexi at $35 \mathrm{n}$ sample application paos were not remioved until completion of the $t$ un.

A constant power source wats tound to de necessary, sirke to $\alpha$ tain ancyuat resolution of the protein bands at pti $8-9$, voltages in excess of low $v$ must be used. Constant power control bedps prevent loculazed overbeating dur ins the $\mathrm{r}(\mathrm{n}$. In addition, isoelectric tocusing was pertormed at $4 \mathrm{~K}$ usiny
$\mathrm{K} 2 \mathrm{~K}$ controlled temperature circulating water unit (brinkman Instruments).

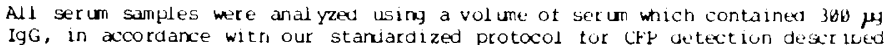
IgG, in accoraance with our standardized protocol tor ch' detection descrived
previousiy (11).

reading of the pritgradent, tixing, staining, and destaining of the get were per tormed as describes previously (11) with the tollowing moditication.

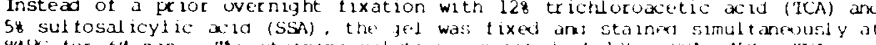

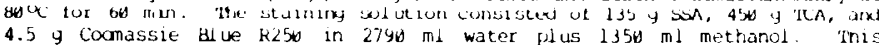

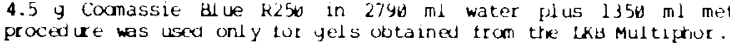

KESULT'S

Typical results obtained tor the protein banding patterns of if homozyote heterozyyote, nomal heal thy control, and normal patient control (patients with bronchial asthma) sera are shown in $\mathrm{Fig}$. 1. The $\mathrm{PH}$ gradient as estimated with a sur face $\mathrm{pH}$ electrode at $4 \%$ is shown in Fiy. 2. Analysis of 61 samples
positive for $F F$ showed that this protein had a pl of $8.57 \pm 0.02$ (Table 1).

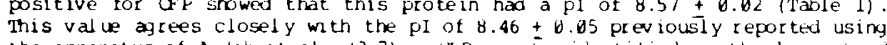
This value ayrees closely with the pI of $8.46 \pm 0.05$ previously reported using
the apparatus of Awdeh et al. $(3,7\}$. (r p can be identitied as the lower band the apparatus of Awdeh et al. 13,7$\}$. If $\mathrm{P}$ can ve identitied as the lower band serum protein pattern (about 7.8 on trom the bottom of the sample application pad, or 8.3 am trom the top of the anodal strip) (Fig. 1). Figure 3 shows an
endaryement of the area containing (rP to clearly demonstrate its location.

In detecting (FP, confusion between distinct banding and diffuse backyround staining must be avolded. The normal control shown in fiy. 3 (the one on the left) appeared to contain a taint (F., band, but camparison of the sample with other crp-positive samples allowed us to ditferentiate this normal control as containing $486 \mu \mathrm{Hg}$ of IgG was $t \mathrm{un}$, this control remained neyative, confiming that it was (F p-negative at $3 w y j$.

filyuge 4 shows a color photoyraph of $\mathrm{pH} 2.5-10.0$ gels containing $2 \mathrm{CF}, 2$ heterozyote and 3 nomal control samples. The band doublet inaicating CFP is marked by lines. A multitude of prote in bands and excellent resolution in the pH 8-9 rasion wete obtained by electrotocusing with our method. CFP is taint
campared with many other serum prote in bands on the yel. Attempts to provide campared with many other serum prote in bands on the yel. Attempts to provide adequate blak and white photayraphs of gel sections containing (FP normally
result in partial loss of protein patterns elsewhere (ct. Figs. 1 and 4). result in partial loss of protein patterns el sewhere
Therefore the present color photoyraph is al so provided

The results of elextrotocusing 28 nomal control sera, 28 heteruzyjote sera, 31 (F) hamozyyote sera, and y sera trom patients with bronchial astrma using the LKB Multiphor and our standiard assay conditions are shown in Table 1 . Iriree of the 36 controls (nonitival plus patient cuntrols, Table 1) were

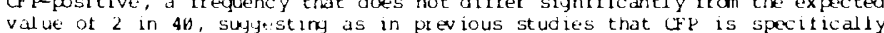
diaynostic tor a metabolic defect uniquely associated with the $C r$ gene. complete ayrefment was tound between the results in Table 1 and those obtatned

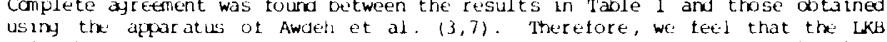
Multiphor can be used to screen sera for (1), and that the band shown in Figs. Multiphor can be used to screen sera for CFp, and that the band shown in figs. publications. In adution, thove recently established the molecular weight

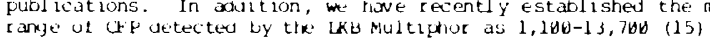

\section{DISCUSSIUN}

Since the preflication of our or ly inal repurt (11) describing the: methodolay

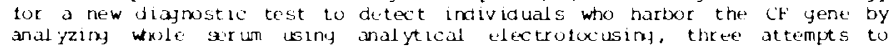
reproduce our timtings have been published $(2,5,6$

smith et al. (5) and 'Inomas et al. (6) clain to have analyzed cif homozygote and nomal control sera using electrotousing mettiods exactly analoyous to ours (11,12); nowever, neither grows usted the akxaratus of Awdeh et al. $(3,7)$ alsting uish textwein ch tramzyyote and control sera.

In previous publications $(8,13)$ we thave indicated three probable reasons tor their lack of success: (a) the apparat us used, (b) improper collection, fouctsing, and storaje of samples, and (c) the methodology usted. Neither
smith et al. (5) nor Thumas et ad. (6) gresented ptotoyraphic evidence that they ever reporodued the protein patterns shown previously (11), yet both yroups went on to modity the technique extensively in attempts to increase the

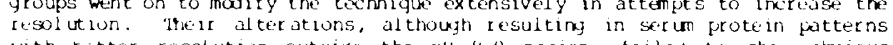
with reiter resolution outside the $\mathrm{pH}$ 8-9 reyion, tailed to show obvious

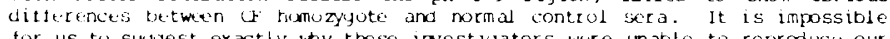
for us tu sugyest exactly why these irvestigators were unable to reproduce our
results, since the ir cummications tiak sutticient detail to permit a carcitul comparison of the dati.

A tew points strould be mase conerning the detection of (fF. first, lucaliza-

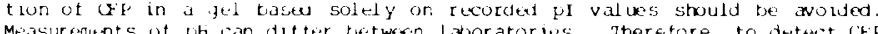
Measurentents of ph can dit ter between 1 aboratorles. Therefore, to detect CF an irvestigator should evaluate the entire uppermost centimeter of the stained

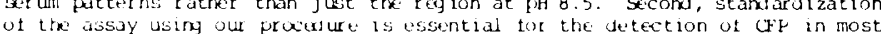

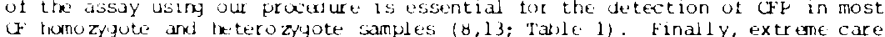

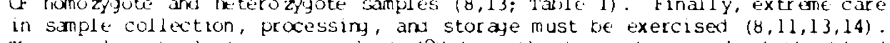
The samples siwulu be processed at 4 \% trom the time of removal of the blood to the time of serun stisa aye at $-7 y^{\circ} C$, and ser un smiples should not be lett at bectrotausing.

In aduitiun to smith te al. (5) and ifromas et al. (6), Alt ankt and co-workers (2) have attempted to detect (fH. Altland et al. (2) ut llized our eartier me.thouls tur tixing and staining to caluce backyround beckyrome stain dee to hijh variatility withen the Iys reyion (2) male it beckyround statn du to high varlability within the lyg rey ion (2) made it molecular-might component touno only in if homozyjote and heterozyjote sera by pertuming i secund step of electrophresis utilizing the sterum protein iraction tocusing at $\mathrm{pH} 8-9(1,2)$. Whether the cationic protein descrited by

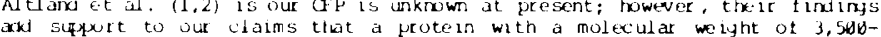

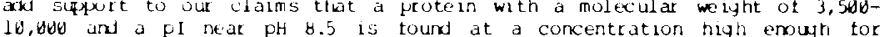
detection in microliter quantities of sera trom most homozyotes and heterozyyote:s for (if $(10,11,15)$.

It is pussible that normal contrul sera also contain small amounts of cir; however, nost ramal contrul sera analyzer were crp-neyative when a vol ume of

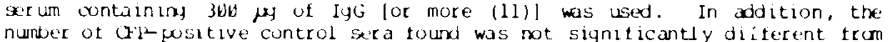
nunber of crl-positive cuntrol sera found was not signiticantly difiterent trom
an expected carr ler trequency of 1 in 20 (ret. 16) in the Caucasian population is expeted carrler trequency of 1 in 20 (ret. 16) in the Caucasian population To out of $11 \mathrm{~b}$ and 2 out of 28 (refs. 10,11; Table 11$)$ If normal sera do
contain low levels of (FP, then the development of a radionmuassay (KIA) to detect ifr may allow us to yuantitate it and establish cutot t levels detinin

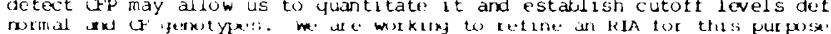

SUMMAKY

To alleviate sume of the problems encounterta by other investigators in our trev luusiy tu provide a more rapid assay fur its detection, we adapted results surgest that the LKb Multiphor can be used to detext CFP and therefore green sia for the CF genes rapidly in a sinyle step. Fitty-eight of 59 horkzyote and heterozygote sera were cip-positive as compared with 2 of 28 normal control sera. Oniy 1 of 8 patients with bronchial asthma incl uded as patient controls was (fp-pusitive,
a specitic marker tor $(F)(9,11)$.

Iwo moditications were reguired tor detection of (FP using the LKB Multiphor: (a) a pH 2.5-14.b yradient instead of a pti 5-16 yradient, and (b) the use of constant power for fucusing to ensure that adequate resolution and a linear $\mathrm{pH}$ gradient (cetweten pH $3.8-9.2$ ) are cotained in only 2 hr without overheating of car in sanple collection, processing, and storaye strould be exercised, and reproducible results. 


\section{FEFERENCES ND NOTES}

1. Altlana, K., Fersonal cominication, August 1976.

2. Altland, K., Scrmidt, S.K., Kaiser, G., and Knoche, W.: Denonstration of Ot haro argotes avd heterozyotes tor cystic fibrosis by a nor-bioloy ical tectrique. Hun angenetik, 28:207 (1975).

3. Fucieh, Z.L., willtamson, A.R., and Askonas, B.A.: Isoelectric tocusing in pol yacrylan ide yed and its application to imunoglooul ins. Nature, 219:6 (1968).

4. DiSant Agrese, P.A., and Dav 1S, P.B.; Ferearch in cystic tibrosis. N Eryl. J. Med., 295:594 (1976).

5. Smith, Q.T., Hanuton, M.J., and Shapiro, B.L.: Letter to the Editor. Pediat, Fes, 18:999 (1976).

6. Thonas, J.M., Merritt, D., and Hodes, M.E. Electrophorettc analysis ot serum proteins in cystic tibrosis. Foolat fes., 11:138 (1977).

7. williamson. A.K.: lsoelectric tocusing of umunoglooulins. In: D.M. weir, Handoos ot Experimental Imurolayy. Ed 2, Crap. of (Blackinel. Scientific Publications, Oxford, 1973).

8. wilson, G.B., Arnaud, P., Monsher, M.T., Fudenbery, H.H.: Detection of cystic fibrosis protein by electrotocusing. Pediat. Fes. 10:1901 (1976).

4. Wilson, G.b., Eurdash, N.M., Arnaud, P., Monsher, M.T., and Fudenber H.H.: Carcinoesbryontc antigen and cystic tibrosis protein in blood fta cystic fibrosis homozygotes and obligate beterozyote cartirrs. Scand $j$. Im unol. $5: 829(1976)$.

10. Wilson, G.H., and Fucenber3, H.H.: Futter puritication an characterization of seru prote ins used to detect cystic tibrosi genotypes by isoelectric focusing. Tex. Fep. B101. Med. 34:51 (1976).

11. WLasn, G.B., fuderberg, H.H., and Jahn, T.L.: Studies on cystic tibrosis using isoelectric tocusing. I. An assay for detection of cystic fibrosi: hanozygotes an beterozygote carriers tran serm. Pediat fes. 9:63 (1975)

12. Wilson, G.b., Jahn, 2.L., and fonseca, J.K.: Denonstration of seru protein difterences in cystic tibrosis by isoelectric tocusing in thin-tayer pol yacrylanide gels, Clin. Chin, Acta 49:79 (1973).

13. Wilson, G.H., Monsher, M.T., and Fudenberg, H.H.: Additional notes on the use of analinical iroelectric tocusing for the detection of cystic fibrosis protein in serun. Fediat. Fes. 11:139 (1977).

14. Wilson, G.b., Monsher, Mi.T., and Fudenberg, H.H.: Studies on cystic tibrosis using isoelectric tocusing 111. Correlation between cystic tibrosis protein and ciliary dyskinesia activity in setum shown by thodified taboit tracteal bloassay. Podiat. Fes. 11:143 (1977)

15. Wilson, G.B., and fudenbery, H.H.: Studies on cystic fiotosis using isoelectric tocusing. IV. Distinction between ciliary dyskinesia activity in cystic tibrosis and asthmatic sera and association of CF protein with the activity in cf serum, pediat. Fes. 11:in the press (1977).

16. wood, K.t., Boat, T.F., and Doerstiuk, C.F.: Cystic tibrosis. Amer, foev, hesp. Dis. 113:833 (1976)

17. The authors qratefully acknowledge the cooperation of Margaret Jenkins, M.D. In cotainios bload specimens tran patients at her clinic and Judith A. Kemp for expert technical assistance. The excellent editorial assistance of Chat les L. Snith is deeply appreciated

16. The research was alded in part by NHH Grants hif-i9g30 and Al-13484, by the South Catolina State Approptation tor weseatch A705 and Dy a Basi o Connor Stafter fexearch Grant tran tie National foundation-March of Dimes. There is currenty a use patent (pending) which cavers the methodol ay deser ined in thas report.

19. This is putication no. 77 trom the Department of Basic and Clintcal im unology and Mictaolology, Medical University of South Carolina.

as. Presented in part at the International Sympsium on Electrofocusing an Isotactopioresis, August $1-4,1976$, Hatbury, Getalany

21. Feguests for reprints sould be adressed to: G.B. wilson. Ph.D. Department of bastc and Clinical Imunology and Microbiolojy, Medical University of south Carolina, Bo Barre Street, Charleston. S.C. 29401 USA.

22. received for putilication. Oct, 12, 1976

23. Accepted for pulication. teo, 17, 1977

TABLE 1

Serum Positivity for Cystic Fibrosis Protein (CFP) as Determined by Electrofocusing with the LKB Multiphor

\begin{tabular}{|c|c|c|c|c|c|c|c|c|c|c|}
\hline \multirow[t]{2}{*}{$\begin{array}{l}\text { Serum } \\
\text { type }\end{array}$} & \multirow[t]{2}{*}{$\begin{array}{l}\text { No. } \\
\text { tested }\end{array}$} & \multicolumn{2}{|l|}{$\begin{array}{l}\text { Donor } \\
\text { age }(\mathrm{yr})\end{array}$} & \multicolumn{2}{|l|}{$\begin{array}{l}\text { IgG leve } 1 \\
(\mathrm{mg} / 100 \mathrm{~m} 1) .\end{array}$} & \multicolumn{2}{|l|}{ Sex } & \multicolumn{3}{|c|}{$\begin{array}{l}\text { CFP } \\
\text { present }{ }^{a}\end{array}$} \\
\hline & & Mean $\pm S . D$. & Range & Mean $\pm S . D$. & range & M & $F$ & + & \pm & - \\
\hline Normal control & 28 & $29 \pm 8$ & $12-48$ & $1034 \pm 269$ & $601-1650$ & 11 & 17 & 2 & 0 & 26 \\
\hline CF heterozygote & 28 & $34 \pm 6$ & $20-57$ & $962 \pm 145$ & $600-2000$ & 9 & 19 & 25 & 2 & 1 \\
\hline CF homozygote & 31 & $12 \pm 4$ & $2.5-25$ & $1298 \pm 518$ & $550-3600$ & 19 & 12 & 29 & 2 & 0 \\
\hline Asthima control ${ }^{b}$ & 8 & $22 \pm 8$ & $10-32$ & $981 \pm 282$ & $660-1500$ & 5 & 3 & 1 & 0 & 7 \\
\hline
\end{tabular}

a +. CFP band present; +, CFP band present but faint; - , CFP band absent.

Analysis of serum sampie containing 300 uq IgG.

$b$ Normal patients with bronchial asthma. 


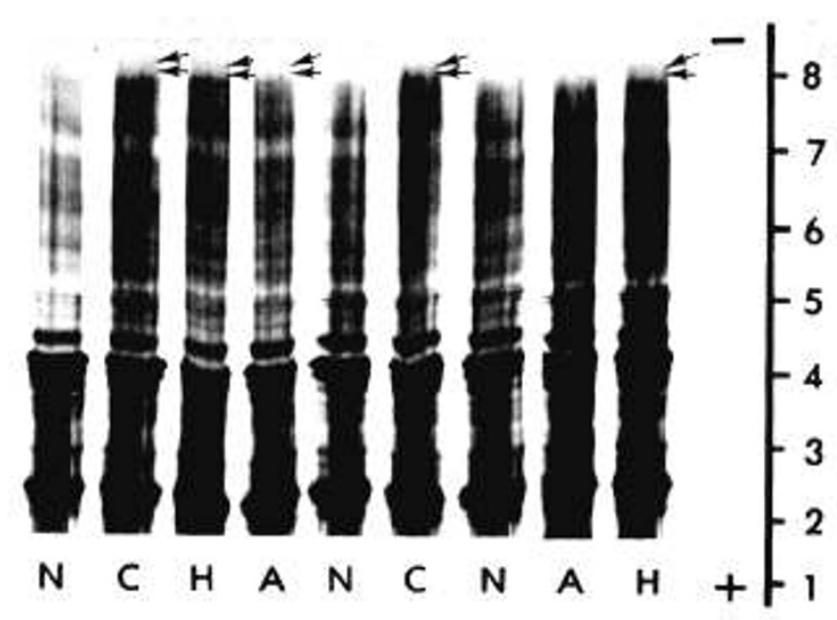

Fir. 1. Wults of isoelectric tocusing of whole serum in a pH 2.5-10.0 gradient. N, nomial control; C. CF homozyote; A, patient with bronchial astrma; H, obl lyate heterozyote. All serum samples contained 360 Hg IgG. The scale on the rlyht indicates the distance in cent umeters fram the bottam of the sample application pad ( 6.5 om from the top of the anocial strip). The arrows Indicate the position of a dand doublet tound in crifositive samples.

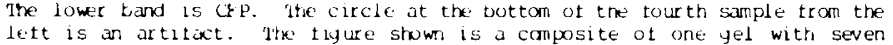
samples and another (tar right) with two samples.

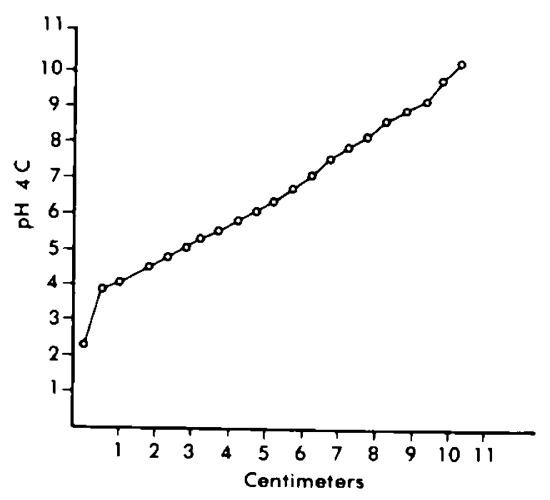

Fiy. 2. Kesults of pH measurement: at $4 \mathrm{O}_{\mathrm{C}}$ tran anode to cathode on the

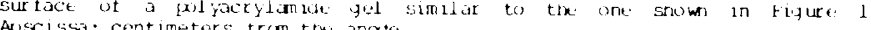

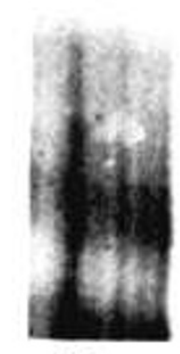

$\mathrm{N}$

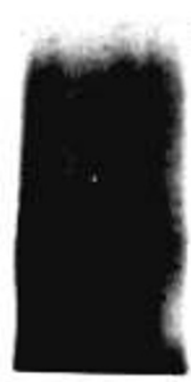

C

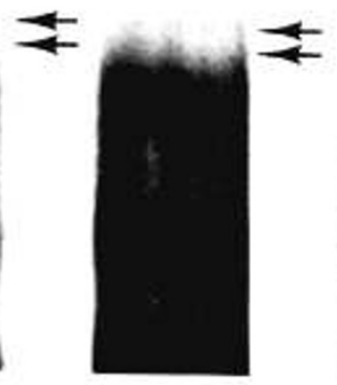

H

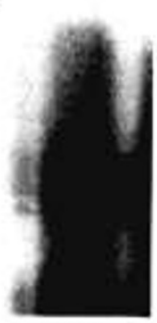

$\mathrm{N}$

Fis. 3. Endaryement if part of the most cathodal reyion of the polyacrylimide gel shown in rigure 1. Samples shown $(\mathrm{N}, \mathrm{C}, \mathrm{H}, \mathrm{N})$ are the tirst three and the titth sainfles in figure l (1ett to righte. Arrows clearly deplet two distinct bands tound in Ci hanuzyyute's and neterozyyotes but not in the hahal the uther $N$ and $A$ samples stown in tigure $l$ are as aark as the $C$ and $h$ samples, yet tall to show is $r$.

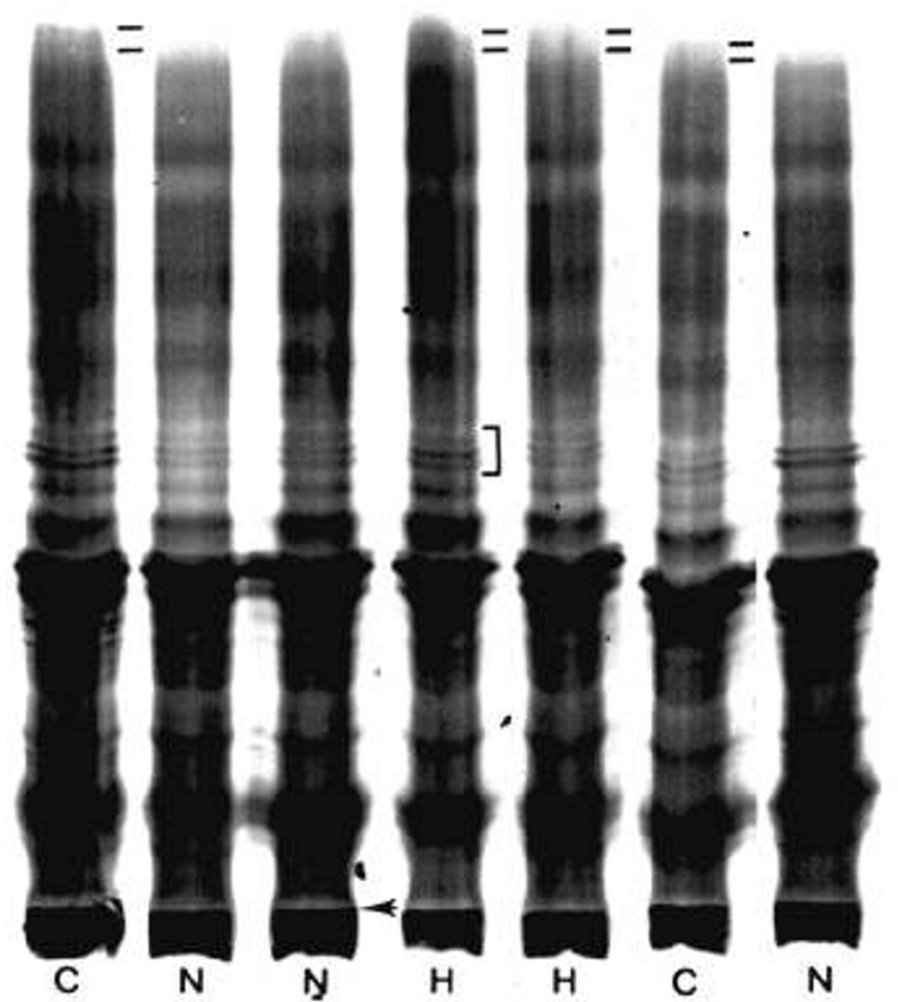

Fly. 4. Whor photouraph ot yels showing the complete serum protein patterns

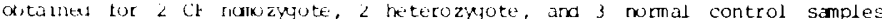
alter elfectrotucueing in a sti $2.5-1 v \cdot b$ yradient. Note that a distinct doublet

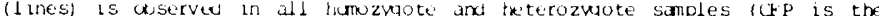
lower line). The normal samples ur, not have a distinct band doublet but do nave diftuse tackifround bunding. Al samples contalned 3 by $\mu y$ ot lyg. Ihe lower bracket encluse's I bahas. 'inese can ve used to tacilitate comparison of

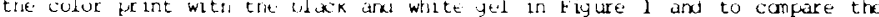
dittertent sariples run. Arrow at bottom indicates the top of the indentation lett by the sallpto defilcition piel. 